\title{
Geochemistry and tectonic setting of the Chah-Bazargan sub-volcanic mafic dykes, south Sanandaj-Sirjan Zone (SSZ), Iran
}

\author{
Abdolnaser FAZLNIA ${ }^{1, *}$ \\ 1 Urmia University, Department of Geology, 57153-165 Urmia, Islamic Republic of Iran
}

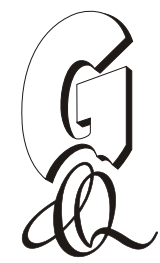

FazInia, A., 2018. Geochemistry and tectonic setting of the Chah-Bazargan sub-volcanic mafic dykes, south Sanandaj-Sirjan Zone (SSZ), Iran. Geological Quarterly, 62 (2): 447-458, doi: 10.7306/gq.1417

Associate editor: Stanisław Mikulski

The Chah-Bazargan sub-volcanic mafic dykes (trachybasalt and basaltic trachyandesite) are located in the south of the Sanandaj-Sirjan Zone (SSZ), Iran. The dyke mineralogy mostly comprises amphibole, clinopyroxene, olivine, orthopyroxene, and plagioclase as phenocrysts and fine-grained plagioclase and some ferromagnesian minerals in the matrix. The rocks are alkaline and shoshonitic in composition. The mafic melts relate to Neotethys subduction activity beneath the southern SSZ in the $\sim$ Eocene-Miocene interval. Markedly positive $\mathrm{Ba}, \mathrm{U}, \mathrm{K}, \mathrm{Pb}$, and $\mathrm{Sr}$ and negative HFSE (high field strength elements: $\mathrm{Nb}, \mathrm{Ta}, \mathrm{Zr}, \mathrm{Hf}, \mathrm{P}$, and Ti) anomalies demonstrate this subduction. The sub-volcanic mafic dykes were produced from a metasomatized upper lithospheric mantle wedge at a depth consistent with the stability field of phlogopite-spinel (or -spinel/garnet) Iherzolite. Geochemical studies on the basis of the rare earth elements (REE) and HFSE, and large ion lithophile elements (LILE) display that the mantle wedge underwent degrees of partial melting averaging between 5 and $15 \%$ to form the Chah-Bazargan sub-volcanic mafic dykes. It is possible that the chemical composition of the rocks was changed due to fractional crystallization and crustal contamination during emplacement.

Key words: alkali sub-volcanic mafic dykes, the Chah-Bazargan intrusions, phlogopite-spinel (or -spinel/garnet) Iherzolite, subduction zone, Neotethys.

\section{INTRODUCTION}

Basalts are erupted in a wide variety of tectonic environments on Earth (e.g., mid-ocean ridges, island arcs, back-arc basins, continental collision zones, intra-plate oceanic islands, large igneous provinces and intra-continental rifts), and collectively they are found on the Earth's surface in greater volume than any other volcanic rock type (Best, 2003; Gill, 2010; Neil et al., 2013, 2015; Haldar and Tišljar, 2014). Various sources and conditions of melting, fractionation, and crystallization of melts in different tectonic settings are reflected, to various degrees, in the chemical composition of igneous rocks such as basalts (e.g., Gill, 2010; Haldar and Tišljar, 2014; Frost and Frost, 2014; Velikoslavinsky and Krylov, 2014). Sub-volcanic mafic melting can occur to result in dykes. Such dykes exist in many geological tectonic settings of west Iran. Basaltic rocks and mafic dykes from the Zagros orogeny have been reported (e.g., Kheirkhah et al., 2009; Azizi et al., 2014; Yousefi et al., 2017).

Western Iran can be divided into a set of three parallel NW-SE trending tectonic zones (Alavi, 1994; Mouthereau et

\footnotetext{
*E-mail: a.fazlnia@urmia.ac.ir and nfazlnia@yahoo.com
}

Received: December 9, 2017; accepted: February 6, 2018; first published online: May 21, 2018 al., 2012; Mohajjel and Fergusson, 2014), namely, the Zagros Fold-Thrust Belt (ZFTB), the Sanandaj-Sirjan zone (SSZ), and the Neogene-Quaternary Urumieh-Dokhtar Magmatic Arc (UDMA; Fig. 1A, B). The Zagros is the largest mountain belt and the most active collisional orogen associated with Arabia/Eurasia convergence. It belongs to the Alpine-Himalayan orogenic system that resulted from the closure of the Neotethys Ocean during the Cenozoic (Mouthereau et al., 2012). The tectonic history of these zones as part of the Tethyan region has been summarized by many authors (Berberian and King, 1981; Alavi, 1994; Omrani et al., 2008; Khadivi et al., 2012; Mouthereau et al., 2012; Mohajjel and Fergusson, 2014). The SSZ juxtaposed various metamorphic and magmatic rocks that mainly formed in Mesozoic time. During the Paleozoic, the SSZ was part of north-east Gondwanaland, separated from the Eurasian Plate by the Palaeo-Tethys Ocean (Golonka, 2004; Mouthereau et al., 2012; Mohajjel and Fergusson, 2014).

From Early Permian to Early Triassic time, the SSZ was situated along the southern margin of the Eurasian Plate, separated from northern Gondwanaland by the Neo-Tethyan Ocean (Mouthereau et al., 2012). During the Mesozoic, the oceanic crust of the Neotethys was subducted beneath the Eurasian plate (Golonka, 2004; Molinaro et al., 2005; Fazlnia et al., 2009, 2013; Agard et al., 2011; Mouthereau et al., 2012; Mohajjel and Fergusson, 2014; Mehdipour Ghazi and Moazzen, 2015; Davoudian et al., 2016; Hassanzadeh and Wernicke, 2016; Honarmand et al., 2017), and the SSZ occupied the position of 


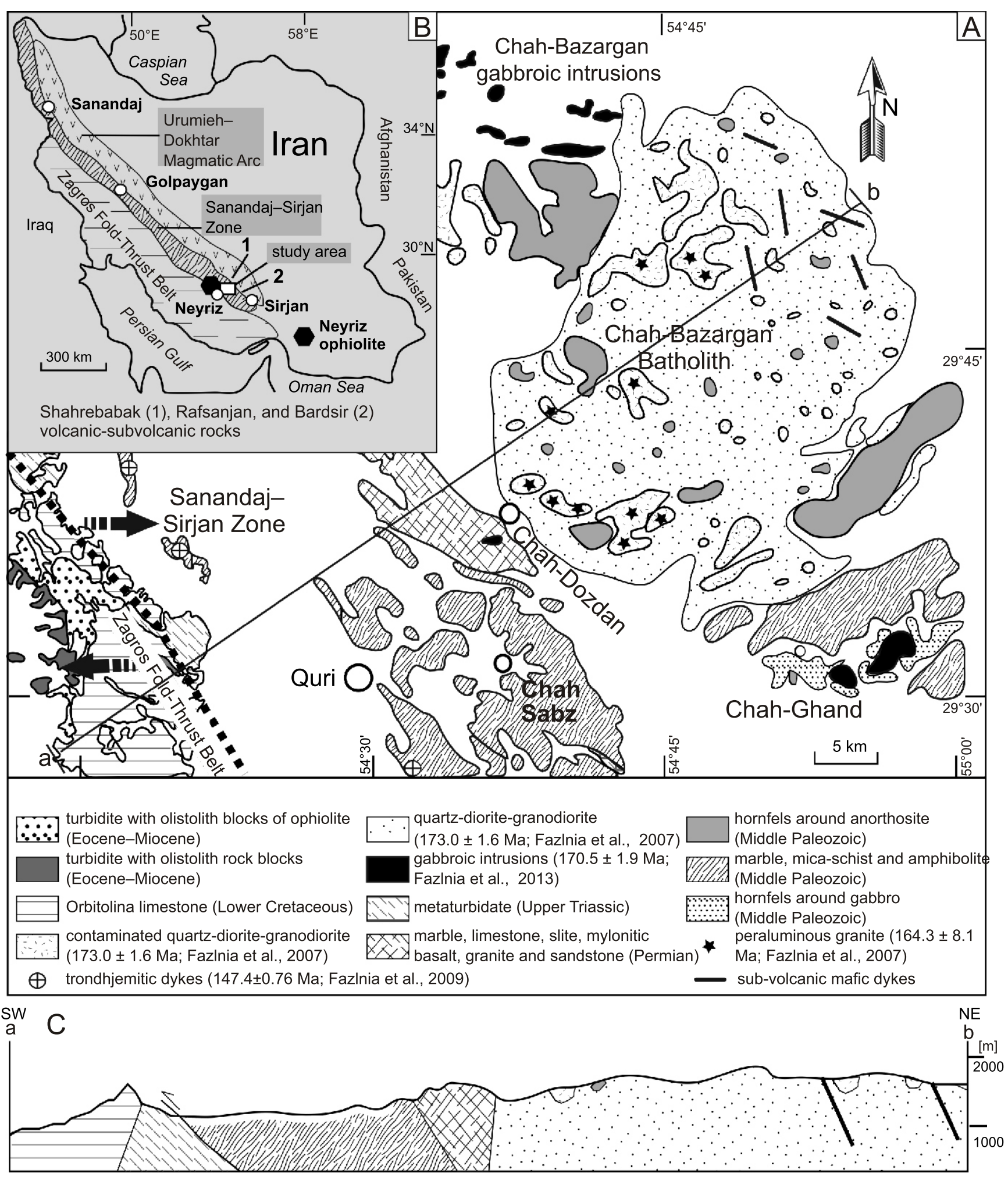

Fig. 1A - simplified geological map of northeasten Neyriz (modified after Sabzehei et al., 1992), Zircon SHRIMP U-Pb isotopic ages of the different rock types from the Chah-Bazargan intrusions are after Fazlnia et al. (2007, 2009, 2013); B - simplified geological map of western Iran (modified after Stöcklin, 1968); C - cross-section showing position of dykes investigated 
a magmatic arc (Berberian and Berberian, 1981; Agard et al., 2005, 2011; Mouthereau et al., 2012). The SSZ in the southeastern part included Paleozoic metamorphic rocks with relatively high-grade metamorphism which in the Middle to Late Triassic were deformed and metamorphosed (Berberian, 1995; Fazlnia et al., 2009; Sheikholeslami, 2015; Karimi and Tabatabaei Manesh, 2016; Hassanzadeh and Wernicke, 2016). The metamorphic lithology in the southern SSZ mainly consists of metapelites, metabasites, marbles, and meta-ultramafic rocks (Berberian and King, 1981; Fazlnia et al., 2009; Sheikholeslami, 2015; Hassanzadeh and Wernicke, 2016). The highest grade metamorphic rocks in the southern SSZ are of upper amphibolite facies (Berberian and King, 1981; Fazlnia et al., 2009).

Subduction-related magmatism in the UDMA was active from the Late Jurassic to the present (e.g., Berberian and King, 1981; Berberian et al., 1982) or the Late Cretaceous to the present (e.g., Hosseini et al., 2017). The final closure of the Neotethys and the collision of the Arabian and Eurasian plates took place during the Late Neogene (Berberian and Berberian, 1981; Alavi, 1994; Golonka, 2004; Molinaro et al., 2005; Omrani et al., 2008; Agard et al., 2011; Mouthereau, 2011; Khadivi et al., 2012; Mouthereau et al., 2012; Mehdipour Ghazi and Moazzen, 2015; Hassanzadeh and Wernicke, 2016). During the same interval, the Zagros Fold-Thrust Belt formed as part of the Alpine-Himalayan mountain chain, extending about $2000 \mathrm{~km}$ from eastern Turkey to the Oman line in southern Iran (Berberian and King, 1981; Alavi, 1994; Agard et al., 2005 2011; Omrani et al., 2008; Mouthereau, 2011; Mouthereau et al., 2012; Mohaijel and Fergusson, 2014; Mehdipour Ghazi and Moazzen, 2015; Hassanzadeh and Wernicke, 2016).

The the Chah-Bazargan sub-volcanic mafic dykes from the southern SSZ of Iran comprise part of the rocks exposed in the Zagros Folf-Thrust Belt (Fig. 1). This study investigates the geochemical and tectonic setting of these dykes. The study of these rocks can help to reconstruct the last stages of Neotethys subduction in the southeastern region of the SSZ, Iran. The rocks formed at the end of subduction, so the present study can establish the relationship between magmatism and the tectonic environment in the southern part of the SSZ. This study examines the geological, petrographic, mineralogical and geochemical characteristics of the Chah-Bazargan sub-volcanic mafic dykes in order to explain their petrogenesis and tectonic environment. Also, the data constrain the origin and emplacement history of the intrusions and contribute to our understanding of the tectono-magmatic evolution of the southern SSZ.

\section{GEOLOGICAL SETTING}

The Chah-Bazargan intrusions, located north-east of Neyriz (Fig. 1), are part of the southern SSZ. The intrusions are composed of granodiorite, quartz diorite, gabbro, troctolite, anorthositic troctolite, anorthosite, wehrlite and clinopyroxenite. These intrusions were emplaced into the low-grade part of the Quri metamorphic complex, which consists primarily of metabasites and marbles, interspersed with metapsammitic, meta-ultramafic, and metapelitic layers. Some outcrops of sedimentary and low-grade metasedimentary rocks can be found as imbricate slices among the high-grade metamorphic rocks because of late stage shearing of the Zagros Fold-Thrust Belt during the late Cenozoic (Berberian and King, 1981; Sabzehei et al., 1992; Fazlnia et al., 2007; Sheikholeslami et al., 2008). The peak pressure and temperature for the Quri metamorphic complex (Fig. 1A) are estimated to be $9.2 \pm 1.2 \mathrm{kbar}$ and $705 \pm 40^{\circ} \mathrm{C}$ resulting from crustal thickening during the Early
Cimmerian Orogeny between 187 and 180 Ma (Fazlnia et al., $2007,2009)$. This event occurred as a result of the initiation of Neotethys subduction beneath central Iran (Fazlnia et al., 2013).

All rock types of the metamorphic complex are strongly sheared and were thrust as imbricate slices over the Neyriz ophiolite (Fig. 1B; Berberian and King, 1981; Shahabpour, 2005; Sheikholeslami et al., 2008; Omrani et al., 2008 Shahbazi et al., 2010; Mouthereau et al., 2012; Mohajjel and Fergusson, 2014). The Neyriz ophiolite is part of the Late Cretaceous ophiolite belt that defines the southwestern edge of the NW-SE-trending SSZ, northeast of the Zagros Fold-Thrust Belt (Stöcklin, 1968, 1977; Stoneley, 1981). The results of recent studies and new ideas about the significance of Late Cretaceous Zagros ophiolites were given by Moghadam and Stern (2011).

After several million years, the Chah-Bazargan intrusions were intruded into the Quri metamorphic complex as a result of Neotethys subduction beneath central Iran (Sheikholeslami, 2015 ) at $170.5 \pm 1.9 \mathrm{Ma}$ (Fazlnia et al., 2013). The tholeiitic melts of the intrusions, related to the start of Neotethys subduction activity beneath the southern SSZ at $\sim 170.5 \pm 1.9 \mathrm{Ma}$, were produced from a metasomatized upper lithospheric mantle wedge at a depth consistent with the stability field of spinel Iherzolite (Fazlnia et al., 2013). The intrusive rocks formed in the Chah-Bazargan intrusions display marked negative HFSE ( $\mathrm{Nb}, \mathrm{P}, \mathrm{Hf}$ and $\mathrm{Ti}$ ) and positive $\mathrm{Ba}, \mathrm{Sr}$, and $\mathrm{U}$ anomalies typical of subduction-related magmas (Fazlnia et al., 2013). The sub-volcanic mafic dykes are located on the eastern edge of the Chah-Bazargan intrusions (Fig. 1A, C).

Additionally, the western edge of the Quri metamorphic complex underwent Barrovian-type metamorphism at $147.4 \pm 0.76 \mathrm{Ma}$ as a result of crustal thickening during the initiation of the Neo-Tethyan mid-ocean ridge subduction beneath central Iran. The metamorphic event of the garnet amphibolites occurred at pressures and temperatures between 7.5 and $9.5 \mathrm{kbar}$ (at a depth of 25 to $32 \mathrm{~km}$ ) and 680 and $720^{\circ} \mathrm{C}$, respectively, based on the Grt-Hbl and $\mathrm{Hbl}-\mathrm{Pl}$ thermometers and a Grt-Hbl-PI-Qtz barometer (Fazlnia et al., 2009).

There are many Oligocene and Miocene dykes with the same chemical composition and mineralogy near the study area as reported by Moradian (1990), Hassanzadeh (1993) and Aftabi and Atapour (2000), such as the Shahrebabak, Rafsanjan, and Bardsir volcanic-subvolcanic rocks (Fig. 1B) Also, based on the geochemical comparison of the samples studied with the mafic collision zone samples from the Turkish-Iranian Plateau (Neill et al., 2013, 2015), it can be concluded that the dykes studied probably formed during Late Eocene-Miocene interval.

\section{FIELD AND PETROGRAPHIC OBSERVATIONS}

Rock exposures of the sub-volcanic mafic dykes in the study area are consistently of alkali basalt in composition. Based on abundances of the mafic minerals, the dykes are mafic rocks (Fig. 2). Dyke widths vary from several metres to tens of metres. In all exposures, the boundaries between the dykes and country rocks (quartz-diorites and granodiorites of the Chah-Bazargan intrusions) are sharp (Fig. 2A) and the mineralogical compositions of each dyke from the chilled margins toward the centre are the same (Fig. 3). Fragments of the host rocks are present in the dykes. Olivine megacrysts along with amphibole and pyroxene are visible in the rock (Fig. 2B, C). The chilled margins of the dykes are very fine grained. Modal percentages of the large minerals increase toward the centres of 


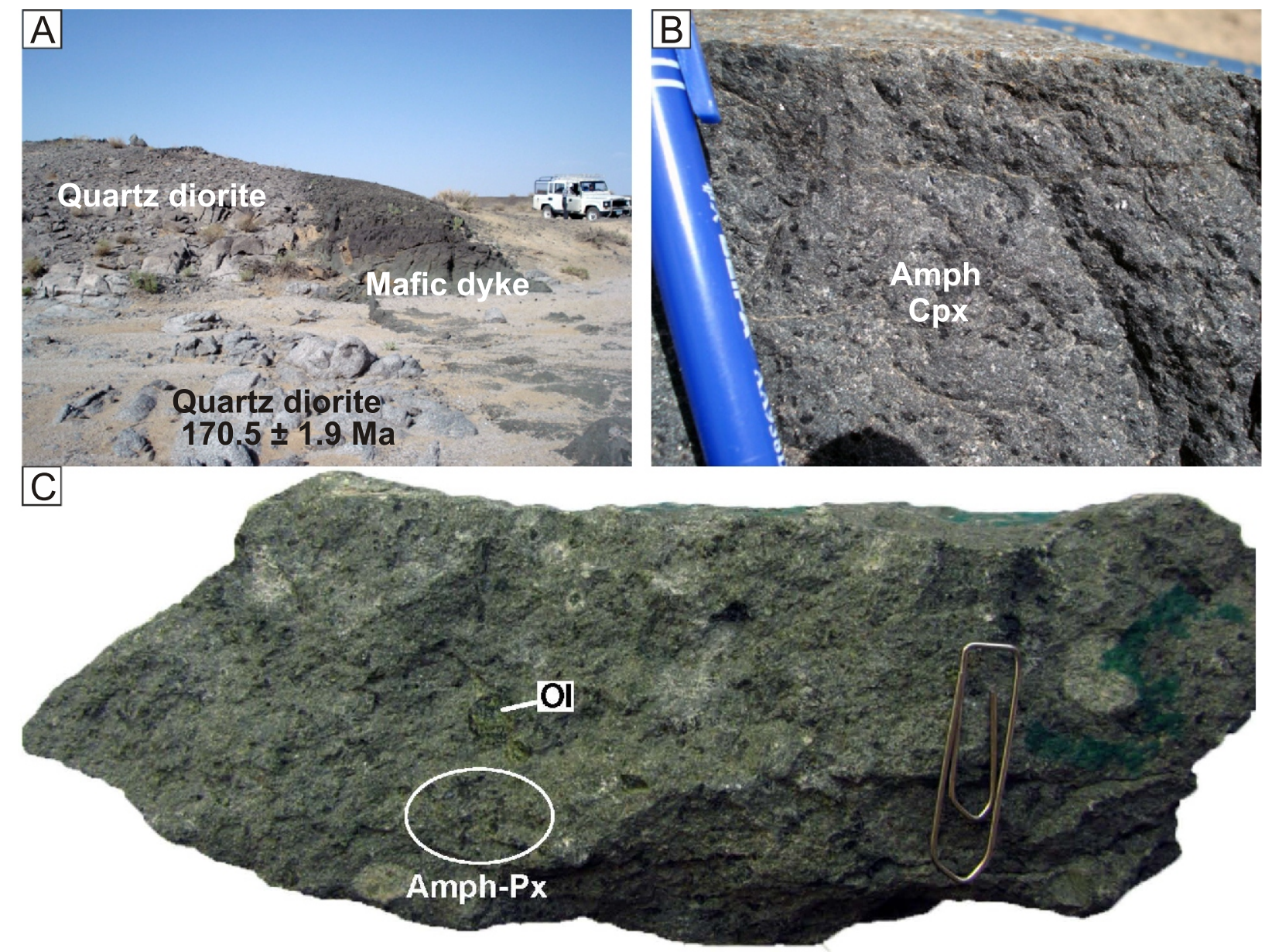

Fig. 2. Photographs of the mafic dykes

A - mafic dykes with a chilled margin; B - specimen of the mafic rocks with large crystals of amphibole (Amph) and clinopyroxene (Cpx); $\mathrm{C}$ - specimen of the mafic rocks from the mafic dykes with large crystals of amphibole, pyroxene (Px) and olivine (OI)

the dykes. This indicates that the dykes intruded into the cold country rocks. Many olivine grains are altered to serpentine.

Mineral assemblages in the mafic dykes (Fig. 3) consist mainly of amphibole (10-12 vol.\%), clinopyroxene (5-7 vol.\%), plagioclase (4-6 vol.\%), orthopyroxene (altered to serpentine; 1-2 vol.\%), and olivine (2-3 vol.\%) along with a very fine-grained matrix and porphyritic texture. The boundaries between the amphibole and clinopyroxene and matrix are mostly sharp and smooth. They are fresh, with no reaction rims between the minerals and the matrix. The minerals are euhedral (Fig. 3A, B). Serpentine is present in framework of the olivine and orthopyroxene (Fig. 3C, D).

Exsolution lamellae of clinopyroxene are present along cleavages of the serpentinized orthopyroxene (Fig. 3E). Olivine has been altered to serpentine (Fig. $3 \mathrm{C}$ ). Reaction boundaries among different crystals of olivine and orthopyroxene and the matrix are gradational. Additionally, these minerals are subhedral or anhedral in shape. Therefore, these minerals were not in equilibrium with the matrix during injection into the quartz-diorite-granodiorite. Also, some amphibole grains show a sieve-like texture in the rims and growths of biotite along the cleavage of the mineral. Therefore, a rapid decrease of the pressure in the magma during injection increased the fluid pres- sure; hence, the olivine and orthopypoxene were unstable and altered to serpentine (Fig. 3C, D), while some amphibole grains developed sieve-like texture in the rims and growth of secondary lamellae of biotite along mineral cleavages (Fig. 3E). Xenocrysts of quartz with reaction margins are observed in the matrix of some specimens (Fig. 3F).

\section{ROCK GEOCHEMISTRY}

\section{ANALYTICAL METHODS}

The rock samples were powdered in an agate mill. LOI (loss on ignition) was determined by heating powders at $1000^{\circ} \mathrm{C}$ for 2 hours. The decreased weights of the powders were then calculated. Appendices $1^{*}$ and 2 list the chemical compositions of 8 representative samples obtained by ICP-MS (inductively coupled plasma-mass spectrometry). The major and trace elements of samples were analysed with an ICP-MS instrument at the ALS Chemex Company of Canada (website: www.acmelab.com; Certificate of analysis: ANK13000382).

* Supplementary data associated with this article can be found, in the online version, at doi: $10.7306 / \mathrm{gq} .1417$ 

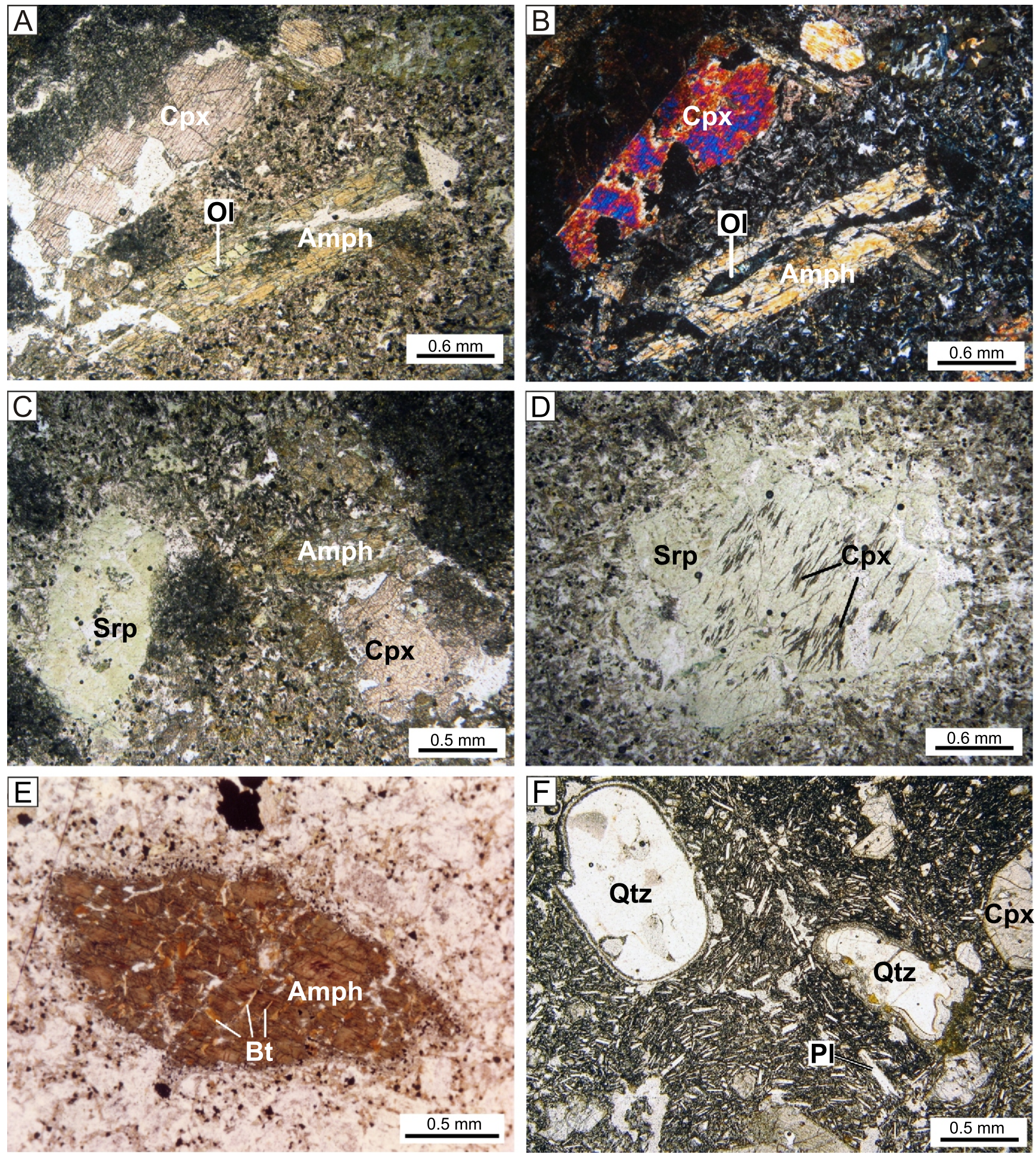

Fig. 3. Photographs of the mafic dykes

A, B - amphibole (Amph) and clinopyroxene ( $\mathrm{Cpx}$ ) in a fine-grained matrix, altered olivine (OI) is present in the amphibole (PPL and XPL light, respectively); C - occurrence of amphibole, clinopyroxene, and altered olivine or orthopyroxene (to serpentine, Srp) with fine-grained matrix (PPL light); D - large grain of orthopyroxene altered to serpentine along with exsolution lamellae of clinopyroxene (PPL light); $\mathbf{E}-$ amphibole grain with sieve-like texture in the rims and growth of secondary lamellae of biotite (Bt) along cleavage planes of the mineral (PPL light); F - xenocrysts of quartz (Qtz) with reactive margins, PI - plagioclase; abbreviations are after Kretz (1983) 

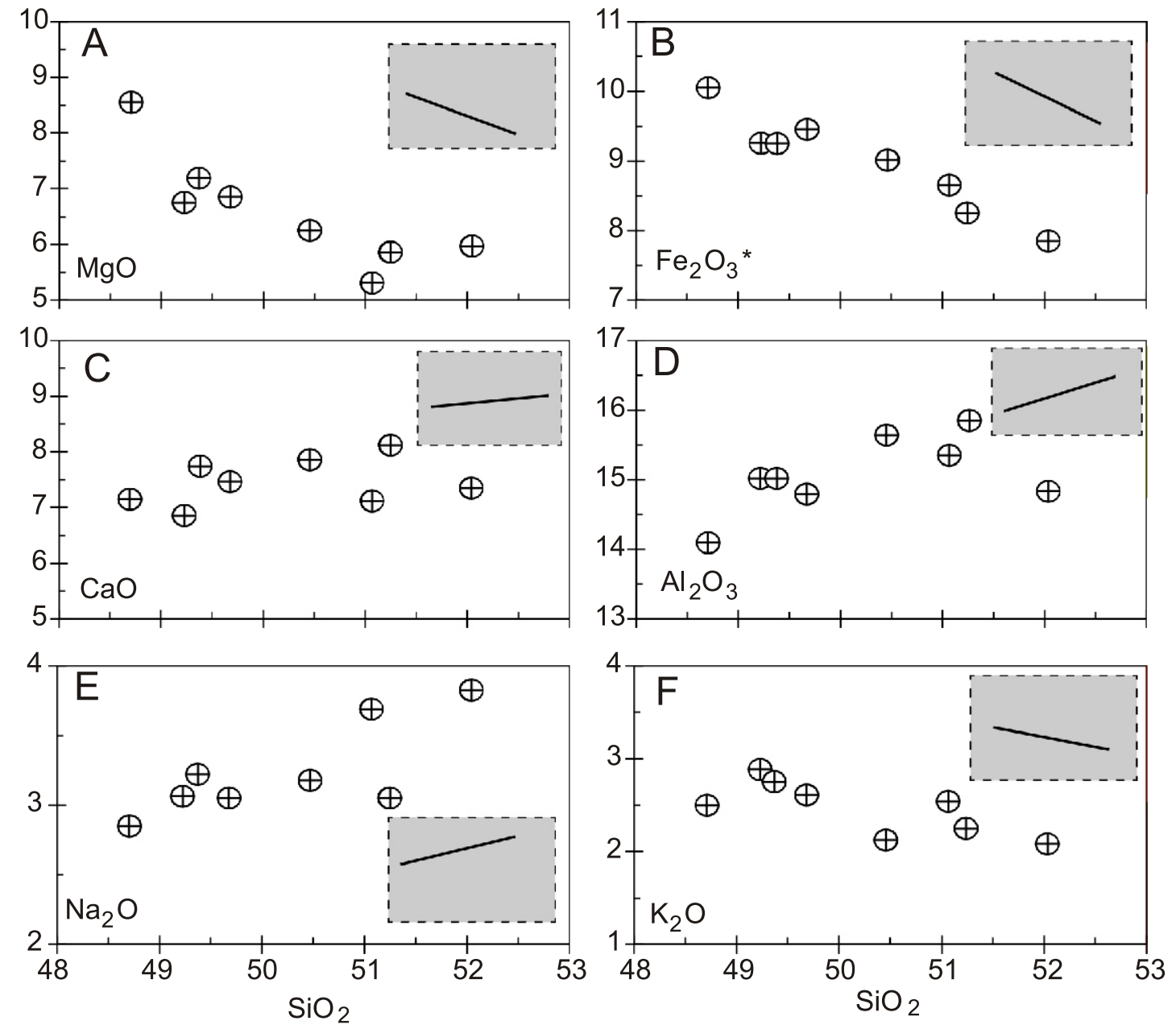

Fig. 4. Binary diagrams of major element oxides vs. $\mathrm{SiO}_{2}$

A - MgO vs. $\mathrm{SiO}_{2} ; \mathbf{B}-\mathrm{Fe}_{2} \mathrm{O}_{3}{ }^{*}$ vs. $\mathrm{SiO}_{2} ; \mathbf{C}-\mathrm{CaO}$ vs. $\mathrm{SiO}_{2} ; \mathbf{D}-\mathrm{Al}_{2} \mathrm{O}_{3}$ vs. $\mathrm{SiO}_{2}$; E $-\mathrm{Na}_{2} \mathrm{O}$ vs. $\mathrm{SiO}_{2} ; \mathbf{F}-\mathrm{K}_{2} \mathrm{O}$ vs. $\mathrm{SiO}_{2}$

\section{GEOCHEMISTRY}

Mafic dykes of the Chah-Bazargan intrusions show limited ranges of $\mathrm{SiO}_{2}, \mathrm{Al}_{2} \mathrm{O}_{3}, \mathrm{Fe}_{2} \mathrm{O}_{3}{ }^{*}, \mathrm{MgO}$, and $\mathrm{CaO}$ content due to limited modal percentages of mafic and felsic minerals. All samples display clear negative correlations between $\mathrm{SiO}_{2}, \mathrm{MgO}$ and $\mathrm{Fe}_{2} \mathrm{O}_{3}$ and obvious positive correlations between $\mathrm{SiO}_{2}$, $\mathrm{Al}_{2} \mathrm{O}_{3}$ and $\mathrm{Na}_{2} \mathrm{O}$ (Appendix 1; Fig. 4). The obvious negative and positive correlations between $\mathrm{SiO}_{2}$ and other oxides demonstrate that fractional crystallization has presumably been an important factor in the geochemical evolution of these rocks. Such a characteristic is supported by decreasing and increasing of incompatible elements correlated with silica (Appendices 1 and 2).

All rock types of the dykes plot on the alkaline series (Fig. 5A). The compositions of the rocks are equivalent to trachybasalt and basaltic trachyandesite on a TAS diagram (Fig. 5A). The occurrence of clinopyroxene, orthopyroxene, and olivine in some samples correlates with the alkaline series. Additionally, samples of the dykes plot on the high-K calc-alkaline and shoshonite series in the $\mathrm{K}_{2} \mathrm{O}(w t . \%)$ vs. $\mathrm{SiO}_{2}$ (wt.\%) diagram (Fig. 5B). For comparison, the samples studied are plot in almost the same fields as the mafic collision zone samples from the Turkish-Iranian Plateau (Neill et al., 2013, 2015) and the Quaternary high-Nb basalts from the north Sanandaj-Sirjan Zone, NW Iran (Azizi et al., 2014).
There are no systematic changes between increase of $\mathrm{SiO}_{2}$ and increase or decrease of all trace elements and REE in the mafic dykes. Element ratios, such as $X_{M g}, L_{n} / Y_{n}, G_{n} / Y_{n}$, $\mathrm{Sm}_{\mathrm{n}} / \mathrm{Yb}_{\mathrm{n}}, \mathrm{Eu}^{*}$, and $\mathrm{K} / \mathrm{Ba}$ decrease in relation with increasing $\mathrm{SiO}_{2}$ (Appendices 1 and 2; Fig. 6). Contents of $\mathrm{K}_{2} \mathrm{O}, \mathrm{Al}_{2} \mathrm{O}_{3}$, and $\mathrm{CaO}$, weakly positive $\mathrm{Sr}$ (Fig. 6A) and very weak Eu (Fig. 6B) anomalies in the mafic dykes suggest that plagioclase contributed only slightly or not at all during the partial melting of the source. Additionally, the Eu/Eu* ratios of the mafic samples (average 0.86 ) may have been dependent on conditions. The averages of the $\mathrm{La}_{n} / \mathrm{Yb}_{n}, \mathrm{La}_{n} / \mathrm{Sm}_{n}$, and $\mathrm{Gd}_{n} / \mathrm{Yb}_{n}$ ratios in the gabbros are $8.05,2.96$, and 1.62 , respectively. This suggests that presumably the mafic rocks segregated from an evolved magma in the chamber.

Negative $\mathrm{Nb}$ and $\mathrm{Ta}$ anomalies suggest that rutile was a residual phase during the generation of the mafic magma. Rutile, ilmenite, and apatite were possible residual phases during the generation of the mafic magma, and as a result, the mafic rocks are not strongly enriched in LREEs (light REE) and all samples show negative $\mathrm{Hf}$ anomalies. This possibility is supported by negative $P$ anomalies in some of the mafic samples (Fig. 6A). Negative $\mathrm{Zr}$ anomalies suggest that zircon was probably a residual refractory phase during the generation of the mafic magma, or the source was initially poor in the element. Changes in the patterns of different elements in the rocks stud- 

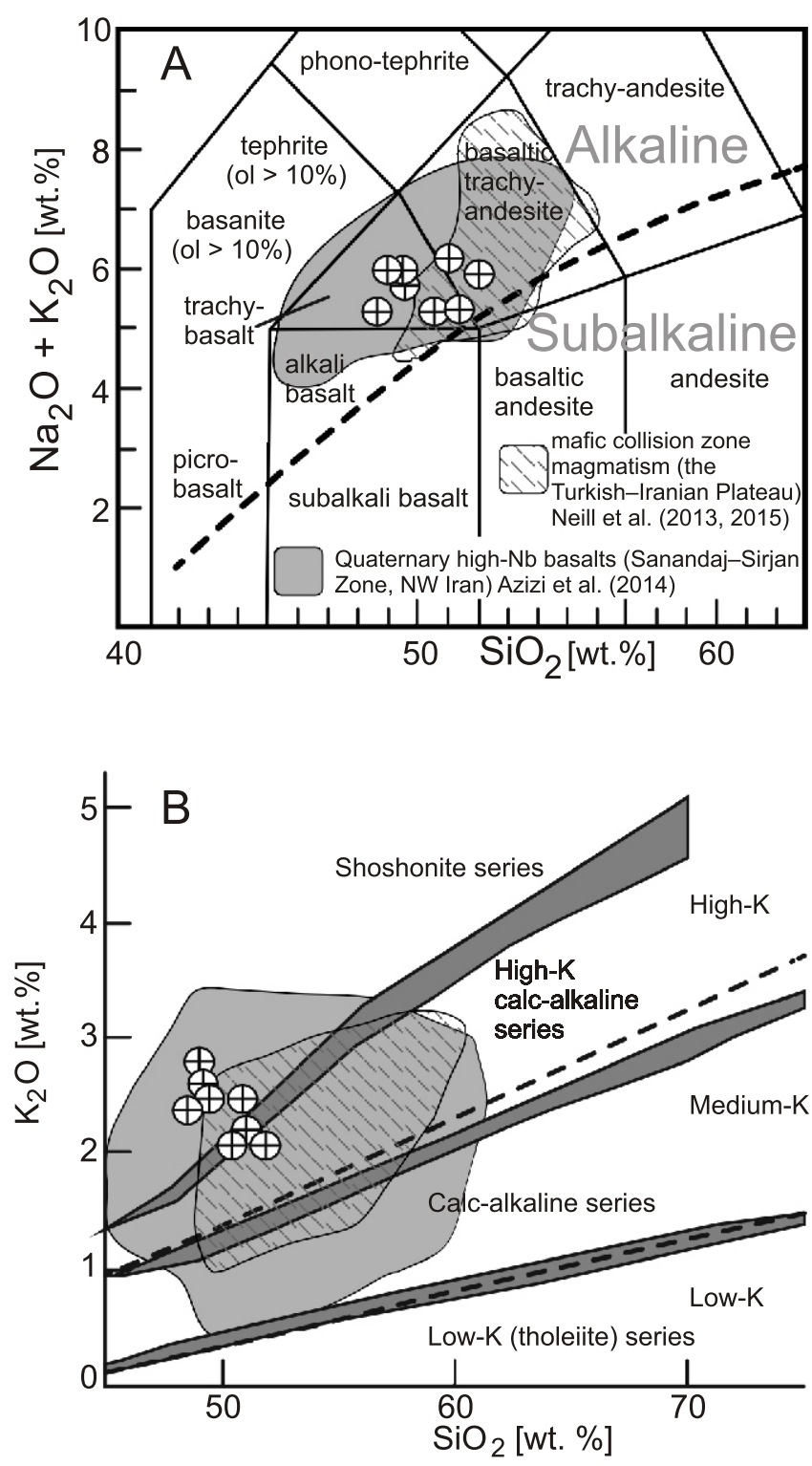

Fig. $5 \mathrm{~A}-\mathrm{Na}_{2} \mathrm{O}+\mathrm{K}_{2} \mathrm{O}$ vs. $\mathrm{SiO}_{2}$ discrimination diagram with field delineated after Middlemost (1994); $\mathrm{B}-\mathrm{K}_{2} \mathrm{O}$ vs. $\mathrm{SiO}_{2}$ discrimination diagram (Rickwood, 1989)

All samples plot between the high-K calc-alkaline, alkaline, and shoshonite series. For comparison, average samples of the mafic collision zone magmatic rocks from the Turkish-Iranian Plateau (Neill et al., 2013, 2015) and the Quaternary high-Nb basalts from the north Sanandaj-Sirjan Zone, NW Iran (Azizi et al., 2014) are shown

ied (Fig. 6A) are almost the same as those of the mafic collision zone samples from the Turkish-Iranian Plateau (Neill et al. 2013,2015 ) and the Quaternary high-Nb basalts from the north Sanandaj-Sirjan Zone, NW Iran (Azizi et al., 2014).

Moderate $\mathrm{La} / \mathrm{Yb}$ ratios (Appendix 2) and low concentrations of HREE in the mafic dykes (Fig. 6A) suggest that spinel was mostly a residual refractory phase and that partial melting was not important in the source region. This is supported by the $\mathrm{Sm} / \mathrm{Yb}$ vs. La/Sm ratios (Appendix 2; Fig. 7) of the mafic dykes from the Chah-Bazargan intrusion. These moderate ratios suggest that partial melting occurred in the stability field of spinel in the mantle source.

\section{DISCUSSION}

\section{MAGMATIC PROCESSES}

Petrographical and geochemical characteristics of the dykes studied suggest that they may be classified as an alkaline and shoshonite series (Fig. 5). They are enriched in alkalis $\left(\mathrm{Na}_{2} \mathrm{O}+\mathrm{K}_{2} \mathrm{O}\right)$, large ion lithophile elements (such as $\mathrm{Rb}, \mathrm{Ba}, \mathrm{Sr}$, and $\left.\mathrm{K}_{2} \mathrm{O}\right)$, and light rare earth elements $\left(\mathrm{La}_{n} / \mathrm{Yb}_{n}\right.$ of 8.02), and features of trace element concentrations are similar to those of some basalts (see tectonic setting). Therefore, it is possible that partial melting processes in the source of the Chah-Bazargan sub-volcanic trachy-basalt and basaltic trachy-andesite dykes are presumably similar to those of the some basalts from the Turkish-Iranian Plateau (Neill et al., 2013, 2015) and the Quaternary high-Nb basalts from the north Sanandaj-Sirjan Zone, NW Iran (Azizi et al., 2014).

Geochemical melting models based on batch and Rayleigh melting modeling can be used to determine possible amounts of partial melting in the migmatitic xenoliths. Based on Figure 8, melting could have occurred as batch melting. Therefore, Shaw's equations (Shaw, 1970) can be used to recognize partial melting into the source. Melting was modeled using the equilibrium batch melting equation:

$$
\frac{C_{i}^{\ell}}{C_{i}^{0}}=\frac{1}{D(1-F)+F}
$$

where: $i$ - the element of interest, $C_{i}^{0}$ - the original concentration in the solid phase (and the concentration in the whole system), $C_{i}^{\ell}-$ the concentration in the liquid (or melt), $F-$ the melt fraction (i.e., mass of melt/mass of system) and $D$ - the partition coefficient of the element of interest: $D=C_{i}^{s} / C_{i}^{\ell} ; C_{i}^{s}$ - the concentration remaining in the solid.

This equation is extremely useful in describing the relative enrichment or depletion of a trace element in the liquid as a function of the degree of melting. Two approximations are often useful. First consider the case where $D<<F$. In this case $C_{i}^{\ell} / C_{i}^{0} \approx 1 / F$, that is, the enrichment is inversely proportional to the degree of melting. This is the case for highly incompatible elements at all but the smallest degrees of melting. Now consider the case where $F$ approaches 0 . In this case $C_{i}^{\ell} / C_{i}^{0} \approx 1 / D$, and the enrichment is inversely proportional to the partition coefficient. Thus the maximum enrichment possible in a partial melt is $1 / D$. For highly compatible elements, which are those with large $D$ such as $\mathrm{Ni}$, the depletion in the melt is $1 / D$ when $F$ is small and is relatively insensitive to $F$.

The averages of the major and trace elements of the Chah-Bazargan sub-volcanic trachy-basalt and basaltic trachyandesite dykes were used (Appendix 2). Thus, the concentrations of the different elements from the average initial protolith $\left(C_{i}^{0}\right.$; spinel peridotite from McDonough, 1991) and the mafic samples $\left(C_{i}^{\ell}\right)$ were considered (Appendix 2).

Simple trace-element modeling was used to test whether the Chah-Bazargan trachybasalt and basaltic trachyandesite dykes bear compositions consistent with derivation by partial melting at in the stability field of spinel in the mantle source. Bulk partition coefficients were calculated assuming 1\%, 5\%, $10 \%, 20 \%, 30 \%, 40 \%$, and $50 \%$ partial melting (Appendix 3).

From the results, summarized in Appendix 3 and Figure 6, it is apparent that the behaviour of all elements, such as the REEs (La to Lu), HFSE ( $\mathrm{Zr}, \mathrm{Ta}, \mathrm{Nb}, \mathrm{U}, \mathrm{Hf}, \mathrm{Y}, \mathrm{P}, \mathrm{Ti}$ ), Ba, Pb, K, 

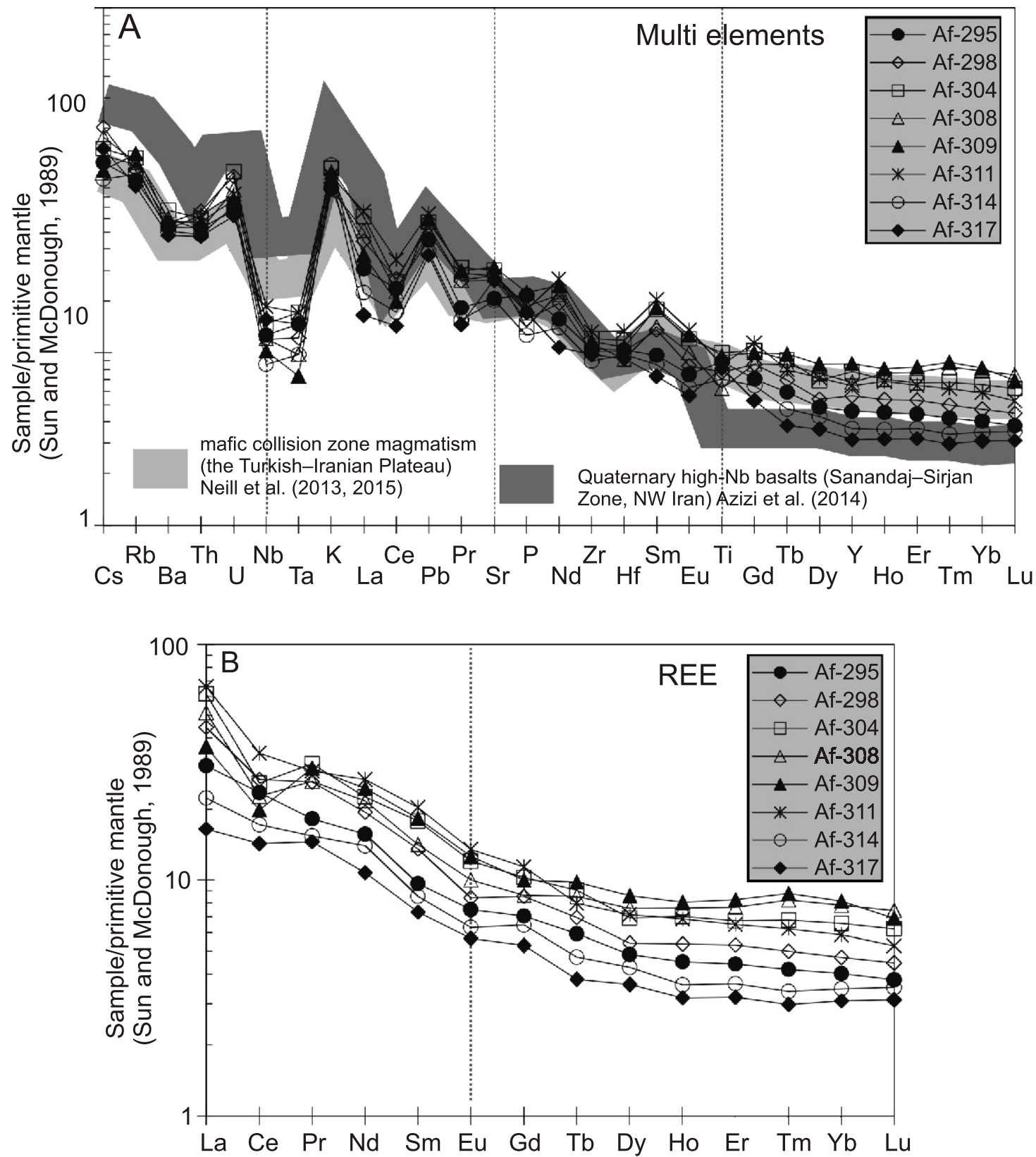

Fig. 6. Primitive mantle normalized multi-element and REE plots

A - normalized multi-element diagram for mafic dykes; B - normalized REE diagram for mafic dykes; normalization values after Sun and McDonough (1989); for comparison see Figure 5

$\mathrm{Rb}$, and $\mathrm{Sr}$ is largely sensitive to source enrichment, but insensitive to the amounts of the main and accessory minerals in the residue (mantle source). Therefore, the major proportions of the minerals cannot generally be a cause of depletion or enrichment in the magma during the partial melting of the source. Hence, partition coefficients decrease with increasing levels of partial melting in the source (Appendix 3).

Considering more incompatible elements such as REE and HFSE, and LILE indicates that relatively modest degrees (average between 10 and $15 \%$ ) of partial melting are permissible (Appendix 3). Additionally, trace-element modeling based on $\mathrm{Sm} / \mathrm{Yb}$ vs. Sm (Fig. 8) diagram shows that a spinel or spinel-garnet Iherzolite mantle source has experienced degrees of partial melting of $\sim 5-15 \%$.
Alkaline rocks generally occur in three principal settings (Winter, 2014): (1) continental rifts, (2) continental and oceanic intraplate settings with no clear tectonic control, and (3) subduction zones, particularly in back-arc settings or in the waning stages of activity. A number of processes are thought to be involved in the genesis of alkali mafic rocks, including: (1) contamination of ultrabasic magma with crustal material (Fitton and Upton, 1987; Srivastava and Chalapathi Rao, 2007); (2) extreme differentiation of basic magma enriched in $\mathrm{CO}_{2}$ and $\mathrm{H}_{2} \mathrm{O}$ (Currie and Williams, 1993; Mitchell et al., 1996; Winter, 2014); and (3) low degree partial melting of metasomatized continental lithospheric mantle (Thorpe, 1982; Morris and Pasteris, 1987; Rock, 1991). A few samples show evidence for crustal assimilation (Fig. 3F). This evidence includes partially 


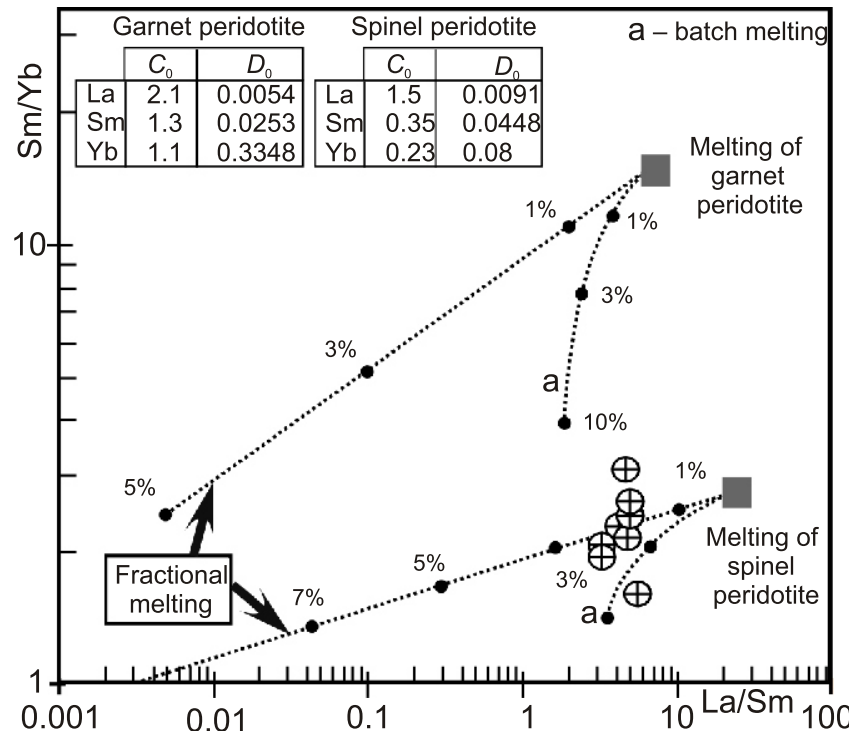

Fig. 7. Sm/Yb vs. La/Sm plot showing theoretical melting curves plotted along with the basic samples from the Chah-Bazargan mafic dykes

Fractional and batch melting equations of Shaw (1970) were used to construct the melting model. F - weight fraction of melt produced (the equilibrium batch melting equation listed above). Modal mineralogy for the spinel- and garnet-peridotites are taken from Wilson (2007) and $\mathrm{Ol}_{0.66}+\mathrm{Opx}_{0.24}+\mathrm{Cpx}_{0.08}+\mathrm{Spl}_{0.02}$ and $\mathrm{Ol}_{0.63}+\mathrm{Opx}_{0.30}+\mathrm{Cpx}_{0.02}+\mathrm{Grt}_{0.05}$, respectively. The trace element composition of the spinel-peridotite $\left(C_{0}\right.$ values $)$ is the average composition of spinel peridotite xenoliths in young (Miocene) alkaline basalts of the Thrace region, NW Turkey (after Keskin, 2005), while that of garnet peridotite is from Frey (1980). Partition coefficient ( $K d s$ or $D$; the equilibrium batch melting equation listed above) between the basaltic melts and minerals given in the inset are compiled from Irving and Frey (1978), Fujimaki et al. (1984), McKenzie and O'Nions (1991) and Rollinson (1993). The bulk partition coefficient $\left(D_{0}\right)$ of each element has been calculated for garnet and spinel peridotite source rock compositions by taking the modal mineralogy of these end members into consideration. The coefficients are given in the inset

digested xenocrysts of quartz in the basaltic trachyandesite dykes. The samples with physical evidence for crustal assimilation (Fig. 3F) are plotted in the crustal contribution field in Figures $9 \mathrm{~A}$ and $10 \mathrm{~A}$. In these processes, it is likely that contamination of crustal materials along with fractional crystallization (assimilation fractional crystallization, AFC; Fig. 4) played important roles in the formation of the geochemical features of the mafic dykes studied (Figs. 9 and 10A), because the trace element concentrations, such as $\mathrm{Rb}, \mathrm{K}, \mathrm{Th}, \mathrm{U}$, and $\mathrm{Pb}$ of the final magmas (Appendix 2; Fig. 6A) are suggested to be high and they are easily modified by crustal contamination. Probably, magmatic differentiation was also important, considering that the dykes show wide ranges of REE patterns (Fig. 6B).

As discussed above, the Chah-Bazargan sub-volcanic trachybasalt and basaltic trachyandesite dykes are suggested to have been derived from the metasomatized upper mantle, forming a basic magma enriched in $\mathrm{CO}_{2}$ and $\mathrm{H}_{2} \mathrm{O}$. Evidence such as negative $\mathrm{Nb}, \mathrm{Ta}, \mathrm{Zr}, \mathrm{Hf}, \mathrm{P}$, and $\mathrm{Ti}$ and positive $\mathrm{Ba}, \mathrm{U}, \mathrm{K}$, $\mathrm{Pb}$, and $\mathrm{Sr}$ anomalies (Fig. 6A), the high-K calc-alkaline, alkaline, and shoshonite series (Fig. 5), and changes in the concentrations of $\mathrm{Th}, \mathrm{Hf}$, and $\mathrm{Ta}$ (Fig. 10A) demonstrate that partial melting of a metasomatized spinel lehrzolite occurred in a typical subduction-related setting. Then, the magma composition was changed due to crustal contamination and magmatic differentiation (FC and AFC) during magma injection and stoping in

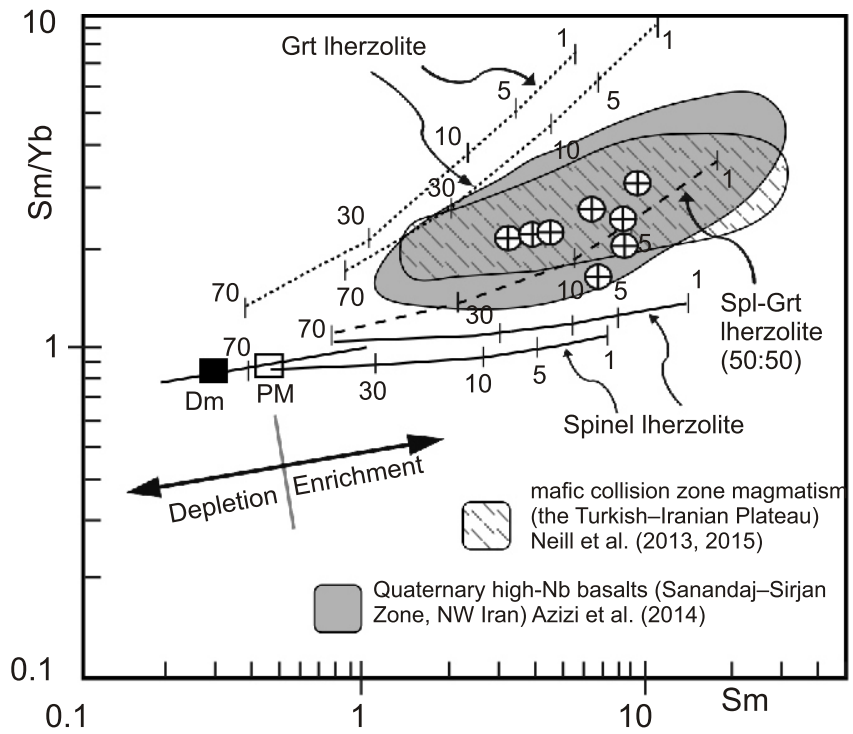

Fig. 8. Plot of Sm/Yb vs. Sm for the mafic dykes in the Chah-Bazargan intrusions

Mantle array (heavy line) defined by depleted MORB mantle (DM, McKenzie and O'Nions, 1991) and primitive mantle (PM, Sun and McDonough, 1989). Melting curves for spinel Iherzolite $(\mathrm{Ol} 53+\mathrm{Op} \times 27+\mathrm{Cp} \times 17+\mathrm{Sp} 11)$ and garnet peridotite $(\mathrm{Ol} 60+\mathrm{Opx} 20+\mathrm{Cp} \times 10+\mathrm{Gt10})$ with both $\mathrm{DM}$ and PM compositions are after Aldanmaz et al. (2000). Numbers along these lines represent the degree of partial melting. For comparison see Figure 5

the crustal chamber. Plotting the samples studied in the fields of the mafic collision zone samples from the Turkish-Iranian Plateau (Neill et al., 2013, 2015) and the Quaternary high-Nb basalts from the north Sanandaj-Sirjan Zone, NW Iran (Azizi et al., 2014), demonstrate that similar processes, such as FC and AFC, have led to the evolution of the parental magma (Fig. 10A).

\section{TECTONIC SETTING}

Ages obtained on the Chah-Bazargan gabbroic intrusions by Fazlnia et al. (2013; $170.5 \pm 1.9 \mathrm{Ma}$; see zircon U-Pb SHRIMP dating section in Fazlnia et al., 2013) and the Chah-Bazargan leuco-quartz diorite-anorthosite-granodiorite batholiths $(173 \pm 6.1 \mathrm{Ma}$ based on zircon U-Pb SHRIMP dating; Fazlnia et al., 2007) showed that these intrusions (Fig. 1A) are related to the early stages of Neotethys subduction beneath the southern SSZ (also, see Shahabpour, 2005 more discussion). Therefore, the southern SSZ was an active continental margin between 175 and $168 \mathrm{Ma}$. Alkaline rocks are typically intruded at a late stage in igneous centres where they occur (Fitton and Upton, 1987; Morris and Pasteris, 1987; Rock, 1987; Winter, 2014).

The dykes studied plotted on the high-K calc-alkaline, shoshonite (Fig. 5B), and alkaline (Fig. 5A) series. Such compositions are most commonly associated with late-orogenic transtension related to low degree lithospheric mantle melting and typically form thin and discontinuous dykes (Fitton and Upton, 1987; Gill, 2010, Scarrow et al., 2011; Winter, 2014). The central Iranian alkaline, potassic calc-alkaline, and shoshonitic volcanic rocks (occurring in the SSZ and UDMB) are part of the Neotethys subduction-related rocks in a continental arc setting (Aftabi and Atapour, 1997, 2000). These rocks were intruded into the crust that is now central Iran during the Eocene-Quaternary (Berberian and King, 1981; Aftabi and 

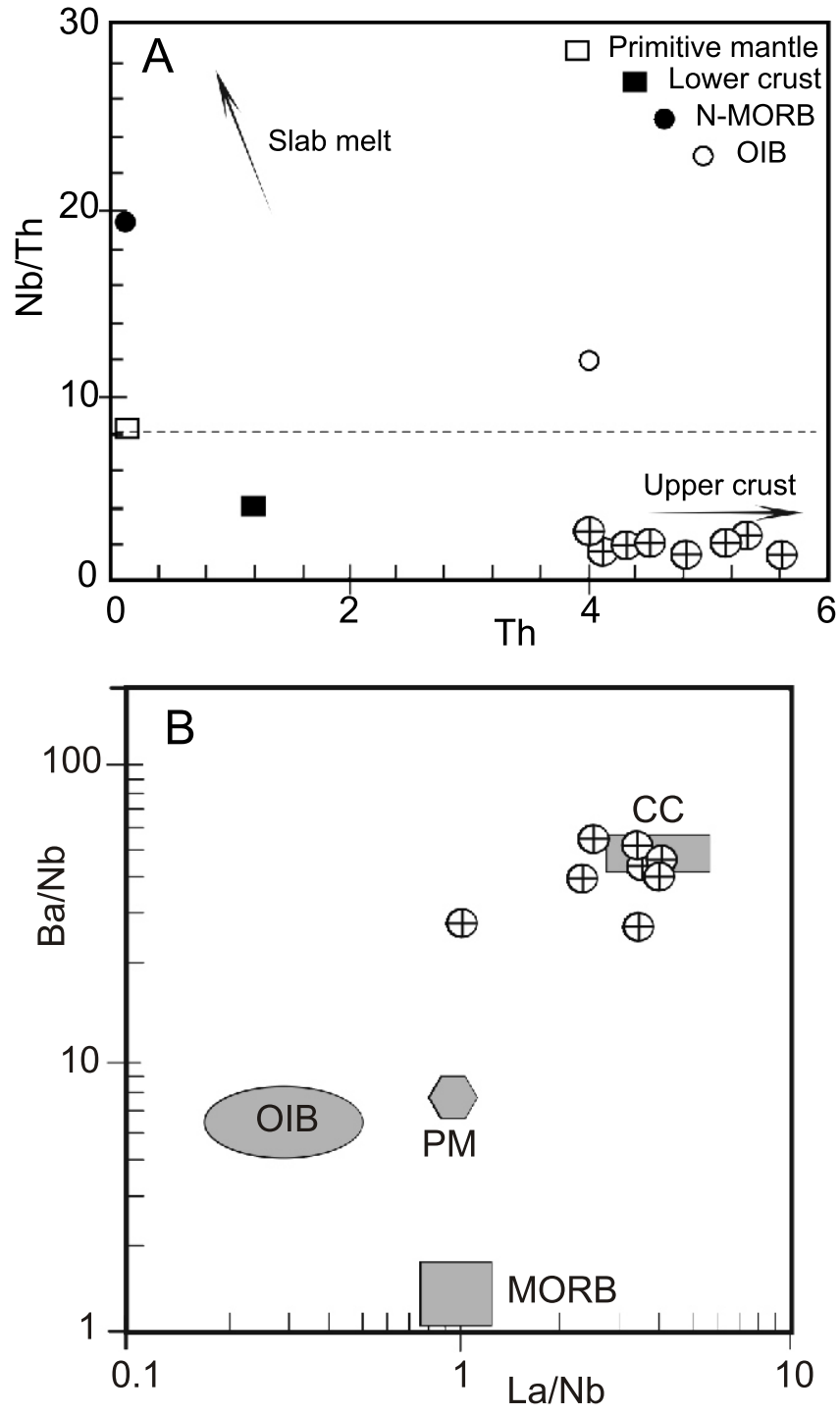

Fig. 9A - plot of $\mathrm{Nb} / \mathrm{Th}$ vs. Th for the mafic dykes; B - plot of $\mathrm{Ba} / \mathrm{Nb}$ vs. La/Nb for the rocks

Values of N-MORB, MORB, OIB and primitive mantle are from Sun and McDonough (1989); values for the lower crust and continental crust are from Wedepohl (1995)

Atapour, 1997, 2000; Aftabi, 1999). Aftabi and Atapour (2000) inferred that these rocks had been derived from an alkaline potassium-rich magma, generated by melting of a phlogopite-bearing subducting plate. Based on the negative $\mathrm{Nb}, \mathrm{Ta}, \mathrm{Zr}, \mathrm{Hf}, \mathrm{P}$, and $\mathrm{Ti}$ and positive $\mathrm{Ba}, \mathrm{U}, \mathrm{K}, \mathrm{Pb}$, and $\mathrm{Sr}$ anomalies, and the Th/Yb vs. Ta/Yb pattern (Fig. 10B), it is possible that the Chah-Bazargan sub-volcanic trachybasalt and basaltic trachyandesite dykes were formed in a metasomatized phlogopite-spinel (or -spinel/garnet) lehrzolite within a typical of subduction-related or syn-collisional setting.

The age of the dykes studied is presumably Eocene-Miocene, and can be connected with the Middle-Late Miocene ( 15-10 Ma) break-off of the north-dipping southern Neotethys oceanic slab beneath the Bitlis and Zagros sutures (Keskin, 2003; Allen and Armstrong, 2008; Zor, 2008; van Hunen and Allen, 2011; Neil et al., 2013, 2015; McQuarrie and van Hinsbergen, 2013; Skolbeltsyn et al., 2014; Azizi et al., 2014) in a syn-collisional geodynamic environment. Finally, the geochemical data indicate that the dykes were formed in subduction-related or syn-collisional setting, though Neil et al. $(2013,2015)$ noted also that "such compositions are most com-
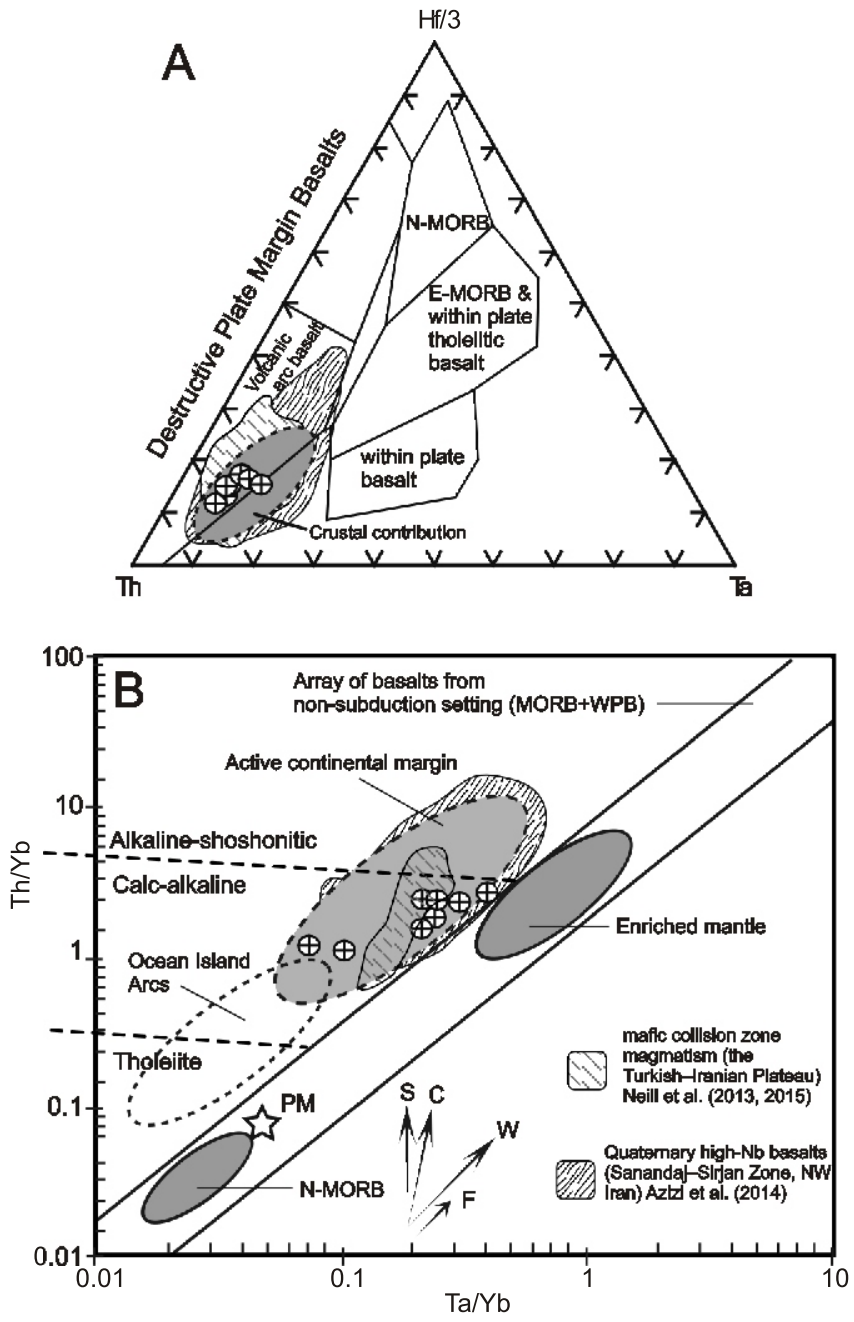

Fig. 10. Tectonic setting discrimination diagrams

A - three angle plot of Th-Hf/3-Ta (Wood, 1980) for the mafic dykes, crustal contribution is after Krmíček (2010); B - plot of Th/Yb vs. $\mathrm{Ta} / \mathrm{Yb}$ (Wilson, 2007) for the rocks, all samples plot in an active continental margin; for comparison see Figure 5; PM - primitive mantle, $\mathrm{S}, \mathrm{C}$ and $\mathrm{W}-$ subduction, collision, and within plate settings, respectively, F - magma fractionation

monly associated with late-orogenic transtension". It is possible that the Chah-Bazargan sub-volcanic trachybasalt and basaltic trachyandesite dykes were derived from a subduction-modified source during orogenic transtension. Finally, the plotting of the samples studied with the mafic collision zone samples from the Turkish-Iranian Plateau (Neill et al., 2013, 2015) and the Quaternary high-Nb basalts from the north Sanandaj-Sirjan Zone, NW Iran (Azizi et al., 2014) in Figure 10B, shows that they are probably formed as a result of the same tectonic environment.

\section{CONCLUSIONS}

The Chah-Bazargan trachybasalt and basaltic trachyandesite melts related to Neotethys subduction activity beneath the southern SSZ approximately in the Eocene-Miocene interval, were produced from a metasomatized upper lithospheric mantle wedge at a depth consistent with the stability field of phlogopite-spinel (or -spinel/garnet) Iherzolite. The rocks studied formed in the Chah-Bazargan intrusions and display marked negative HFSE (Nb, Ta, Zr, Hf, P, and Ti) and positive $\mathrm{Ba}, \mathrm{U}, \mathrm{K}, \mathrm{Pb}$, and $\mathrm{Sr}$ anomalies typical of subduction-re- 
lated magmas. During emplacement, they underwent magmatic transformations and fractional crystallization in an open system, which was resupplied frequently, and by these processes formed the dykes. Simple trace-element modeling based on the REE, HFSE and LILE show that the Chah-Bazargan sub-volcanic mafic dykes were derived as a result of degrees of partial melting averaging between 5 and $15 \%$. The melts were easily modified by crustal contamination and fractional crystallization. These are the causes of the heteroge- neity observed, such as in the REE, in some parts of the Chah-Bazargan sub-volcanic mafic dykes.

Acknowledgements. Financial support from the Iranian Ministry of Science, Research and Technology and from the Urmia University (Iran) are gratefully acknowledged. The author wishes to thank the anonymous reviewers of the paper, for their help.

\section{REFERENCES}

Aftabi, A., 1999. Geochemical aspects of sheared zones as an indication of porphyry Cu-Mo-Au-Ag mineralization at Derehamzeh, Kerman: Iran. Exploration Mining of Geology, 6: 261-267.

Aftabi, A., Atapour, H., 1997. Geochemical and petrological characteristics of shoshonitic and potassic calcalkaline magmatism at Sarcheshmeh and Dehsiahan porphyry copper deposits, Kerman, Iran (in Persian with English abstract). Research Bulletin, Isfahan University, 9: 127-156.

Aftabi, A., Atapour, H., 2000. Regional aspects of shoshonitic volcanism in Iran. Episodes, 23: 119-125.

Agard, P., Omrani, J., Jolivert, L., Mouthereau, F., 2005. Convergence history across Zagros (Iran): constraints from collisional and earlier deformation. International Journal of Earth Sciences (Geologische Rundschau), 94: 401-419.

Agard, P., Omrani, J., Jolivet, L., Whitechurch, H., Vrielynck, B. Spakman, W., Monié, P., Meyer, B., Wortel, R., 2011. Zagros orogeny: a subduction-dominated process. Geological Magazine, 148: 692-725.

Alavi, M., 1994. Tectonic of the Zagros orogenic belt of Iran: new data and interpretations. Tectonophysics, 229: 211-238.

Aldanmaz, E., Pearce, J.A., Thirlwall, M.F., Mitchell, J.G., 2000 Petrogenetic evolution of late Cenozoic, post-collision volcanism in western Anatolia, Turkey. Journal of Volcanology and Geothermal Research, 102: 67-95.

Allen, M.B., Armstrong, H.A., 2008. Arabia-Eurasia collision and the forcing of mid-Cenozoic global cooling. Palaeogeography, Palaeoclimatology, Palaeoecology, 265: 52-58.

Azizi, H., Asahara, Y., Tsuboi, M., 2014. Quaternary high-Nb basalts: existence of young oceanic crust under the Sanandaj-Sirjan Zone, NW Iran. International Geology Review, 56: 167-186.

Berberian, F., Berberian, M., 1981. Tectono-plutonic episodes in Iran. American Geophysical Union, Geodynamics series, 3: 5-32.

Berberian, F., Muir, I.D., Pankhurst, R.J., Berberian, M., 1982. Late Cretaceous and early Miocene Andean-type plutonic activity in northern Makran and Central Iran. Journal of the Geological Society, 139: 605-614.

Berberian, M., 1995. Master blind thrust faults hidden under the Zagros folds: active basement tectonics and surface morphotectonics. Tectonophysics, 241: 193-224.

Berberian, M., King, G.C.P., 1981. Towards a paleogeography and tectonic evolution of Iran. Canadian Journal of Earth Sciences, 18: $210-265$

Best, M.G., 2003. Igneous and Metamorphic Petrology. Blackwell.

Currie, K.L., Williams, P.R., 1993. An Archean calcalkaline lamprophyre suite, northeastern Yilgarn block, Western Australia. Lithos, 31: 33-50.

Davoudian, A.R., Genser, J., Neubauer, F., Shabanian, N., 2016. ${ }^{40} \mathrm{Ar} /{ }^{39} \mathrm{Ar}$ mineral ages of eclogites from North Shahrekord in the Sanandaj-Sirjan Zone, Iran: Implications for the tectonic evolution of Zagros orogeny. Gondwana Research, 37: 216-240.

FazInia, A.N., Moradian, A., Rezaei, K., Moazzen, M., Alipour, S., 2007. Synchronous activity of anorthositic and S-type granitic magmas in the Chah-Dozdan batholith, Neyriz, Iran: evidence of zircon SHRIMP and monazite CHIME dating. Journal of Sciences, IR of Iran, 18: 221-237.
FazInia, A.N., Schenk, V., van der Straaten, F., Mirmohammadi, M.S., 2009. Petrology, geochemistry, and geochronology of trondhjemites from the Quri Complex, Neyriz, Iran. Lithos, 112: 413-433.

FazInia, A.N., Schenk, V., Appel, P., Alizade, A., 2013. Petrology, geochemistry, and geochronology of the Chah-Bazargan gabbroic intrusions in the south Sanandaj-Sirjan zone, Neyriz, Iran. International Journal of Earth Sciences, 102: 1403-1426.

Fitton, J.G., Upton, B.G.J., 1987. Alkaline Igneous Rocks. Blackwell Scientific, Oxford.

Frey, F.A., 1980. The origin of pyroxenites and garnet pyroxenites from Salt Lake Crater, Oahu, Hawaii: trace element evidence. American Journal of Science, 280: 427-449.

Frost, B.R., Frost, C.D., 2014. Essentials of Igneous and Metamorphic Petrology. Cambridge University Press.

Fujimaki, H., Tatsumoto, M., Aoki, K., 1984. Partition coefficients of $\mathrm{Hf}, \mathrm{Zr}$ and $\mathrm{REE}$ between phenocrysts and groundmasses. Proceedings of the Fourteenth Lunar and Planetary Science Conference, Part 2. Journal of Geophysical Research and Supplement, 89: 662-672.

Gill, R., 2010. Igneous Rocks and Processes: A Practical Guide. Wiley-Blackwell.

Golonka, J., 2004. Plate tectonic evolution of the southern margin of Eurasia in the Mesozoic and Cenozoic. Tectonophysics, 381: 235-273.

Haldar, S.K., Tišljar, J., 2014. Introduction to Mineralogy and Petrology. Elsevier.

Hassanzadeh, J., 1993. Metallogenic and tectonomagmatic events in the SE sector of Cenozoic active continental margin of Central Iran (Sharebabak area), Kerman province. Ph.D. thesis, University of California, Los Angeles.

Hassanzadeh, J., Wernicke, B.P., 2016. The Neotethyan Sanandaj-Sirjan zone of Iran as an archetype for passive margin-arc transitions. Tectonics, 35: 586-621.

Honarmand, M., Li, X-H., Nabatian, G., Neubauer, F., 2017. In-situ zircon U-Pb age and $\mathrm{Hf}-\mathrm{O}$ isotopic constraints on the origin of the Hasan-Robat A-type granite from Sanandaj-Sirjan zone, Iran: implications for reworking of Cadomian arc igneous rocks. Mineralogy and Petrology, 111: 659-675.

Hosseini, M.R., Hassanzadeh, J., Alirezaei, S., Sun, W., Li, C.-Y., 2017. Age revision of the Neotethyan arc migration into the southeast Urumieh-Dokhtar belt of Iran: geochemistry and U-Pb zircon geochronology. Lithos, 284-285: 296-309.

Irving, A.J., Frey, F.A., 1978. Distribution of trace elements between garnet megacrysts and host volcanic liquidus of kimberkitic to rhyolitic composition. Geochimica et Cosmochimica Acta, 42: 771-787.

Karimi, S., Tabatabaei Manesh, S.M., 2016. Textural relations, P-T path, polymetamorphism and also geodynamic significance of metamorphic rocks of the Aligudarz-Khonsar region, Sanandaj-Sirjan zone, Iran. Petrology, 24: 100-115.

Keskin, M., 2003. Magma generation by slab steepening and breakoff beneath a subduction-accretion complex: an alternative model for collision-related volcanism in Eastern Anatolia, Turkey. Geophysical Research Letters, 30: 1-4. 
Keskin, M., 2005. Domal uplift and volcanism in a collision zone without a mantle plume: evidence from Eastern Anatolia. http://www.mantleplumes.org/

Khadivi, S., Mouthereau, F., Barbarand, J., Adatte, T., Lacombe, O., 2012. Constraints on paleodrainage evolution induced by uplift and exhumation on the southern flank of the Zagros-Iranian Plateau. Journal of the Geological Society, 169: 83-97.

Kheirkhah, M., Allen, M.B., Emami, M., 2009. Quaternary syn-collision magmatism from the Iran/Turkey borderlands. Journal of Volcanology and Geothermal Research, 182: 1-12.

Kretz, R., 1983. Symbols for rock-forming minerals. American Mineralogist, 68: 277-279.

Krmíček, L., 2010. Pre-Mesozoic lamprophyres and lamproites of the Bohemian Massif (Czech Republic, Poland, Germany, Austria). Mineralogia Polonica, Special Papers, 37: 38-46.

McDonough, M., 1991. Chemical and isotope systematics of continental lithospheric mantle. In: Kimberlites, Related Rocks and Mantle Xenoliths (eds. H.O.A. Meyer and O.H. Leonardos): 478-485. Companhia de Pesquisa de Recursos Minerais, Rio de Janeiro.

McKenzie, D.P., O'Nions, R.K., 1991. Partial melt distribution from inversion of rare earth element concentrations. Journal of $\mathrm{Pe}$ trology, 32: 1021-1091.

McQuarrie, N., van Hinsbergen, D.J.J., 2013. Retrodeforming the Arabia-Eurasia collision zone: age of collision versus magnitude of continental subduction. Geology, 41: 315-318.

Mehdipour Ghazi, J., Moazzen, M., 2015. Geodynamic evolution of the Sanandaj-Sirjan zone, Zagros orogen, Iran. Turkish Journal of Earth Sciences, 24: 513-528.

Middlemost, E.A.K., 1994. Naming materials in the magma/igneous rock system. Earth-Science Reviews, 37: 215-224.

Mitchell, R.H., Eby, G.N., Martin, R.F., 1996. Alkaline rocks: petrology and mineralogy. Canadian Mineralogist, 34: 173-484.

Moghadam, H.S., Stern, R.J., 2011. Geodynamic evolution of late Cretaceous Zagros ophiolites: formation of Oceanic Lithosphere above a Nascent Subduction Zone. Geological Magazine, 148: 762-801.

Mohajjel, M., Fergusson, C.L., 2014. Jurassic to Cenozoic tectonics of the Zagros Orogen in northwestern Iran. International Geology Review, 56: 263-287.

Molinaro, M., Zeyen, H., Laurencin, X., 2005. Lithospheric structure underneath the SE Zagros Mountains, Iran: recent slab break-off? Terra Nova, 25: 1-6.

Moradian, A., 1990. Petrological and economical evaluation of feldspathoidal rocks of northern Shahrebabak, Kerman (in Persian). M.Sc. thesis, Tehran University.

Morris, E.M., Pasteris, J.D., 1987. Mantle metasomatism and alkaline magmatism. GSA Special Paper, 215.

Mouthereau, F., 2011. Timing of uplift in the Zagros belt//ranian plateau and accommodation of late Cenozoic Arabia/Eurasia convergence. Geological Magazine, 148: 726-738.

Mouthereau, F., Lacombe, O., Vergés J., 2012. Building the Zagros collisional orogen: timing, strain distribution and the dynamics of Arabia/Eurasia plate convergence. Tectonophysics, 532-535: 27-60.

Neill, I., Meliksetian, K., Allen, M.B., Navasardyan, G., Karapetyan, S., 2013. Pliocene-Quaternary volcanic rocks of NW Armenia: magmatism and lithospheric dynamics within an active orogenic plateau. Lithos, 180-181: 200-215.

Neill, I., Meliksetian, K., Allen, M.B., Navasardyan, G., Kuiper, K., 2015. Petrogenesis of mafic collision zone magmatism: the Armenian sector of the Turkish-Iranian Plateau. Chemical Geology, 403: 24-41.

Omrani, J., Agard, P., Whitechurch, H., Benoit, M., Prouteau, G., Jolivet, L., 2008. Arc-magmatism and subduction history beneath the Zagros Mountains, Iran: a new report of adakites and geodynamic consequences. Lithos, 106: 380-398.

Rickwood, P.C., 1989. Boundary lines within petrologic diagrams which use oxides of major and minor elements. Lithos, 22 247-263.

Rock, N.M.S., 1987. The nature and origin of lamprophyres: an overview. Geological Society Special Publications, 30: 191-226.

Rock, N.M.S., 1991. Lamprophyres. Blackie and Sons Ltd.
Rollinson, H.R., 1993. Using Geochemical Data: Evaluation, Presentation, Interpretation. Longman Scientific and Technical, John Wiley Sons.

Sabzehei, M., Navazi, M., Ghavidel, M., Hamdi, S.B., 1992. Geological map of Neyriz (scale: 1:250,000). Geological Survey of Iran, Tehran, Iran.

Scarrow, J.H., Francisco, Molina, J., Bea, F., Montero, P., Vaughan, A.P.M., 2011. Lamprophyre dikes as tectonic markers of late orogenic transtension timing and kinematics: a case study from the Central Iberian Zone. Tectonics, 30, doi.org/10.1029/2010TC002755

Shahabpour, J., 2005. Tectonic evolution of the orogenic belt in the region located between Kerman and Neyriz. Journal of Asian Earth Sciences, 24: 405-417.

Shahbazi, H., Siebe, W., Pourmoafee, M., Ghorbani, M., Sepahi, A.A., Shang, C.K., Vousoughi Abedini, M., 2010. Geochemistry and $\mathrm{U}-\mathrm{Pb}$ zircon geochronology of the Alvand plutonic complex in Sanandaj-Sirjan Zone (Iran): new evidence for Jurassic magmatism. Journal of Asian Earth Sciences, 39: 668-683.

Shaw, D.M., 1970. Trace element fractionation during anatexis. Geochimica et Cosmochimica Acta, 34: 237-243.

Sheikholeslami, M.R., 2015. Deformations of Palaeozoic and Mesozoic rocks in southern Sirjan, Sanandaj-Sirjan Zone, Iran. Journal of Asian Earth Sciences, 106: 130-149.

Sheikholeslami, M.R., Pique, A., Mobayen, P., Sabzehei, M., Bellon, H., Hashem Emami, M., 2008. Tectono-metamorphic evolution of the Neyriz metamorphic complex, Quri-Kor-e-Sefid area (Sanandaj-Sirjan Zone, SW Iran). Journal of Asian Earth Sciences, 31: 504-521.

Skolbeltsyn, G., Mellors, R., Gök, R., Türkelli, N., Yetirmishli, G., Sandvol, E., 2014. Upper mantle S wave velocity structure of the East Anatolian-Caucasus region. Tectonics, 33: 207-221.

Srivastava, R.K., Chalapathi Rao, N.V., 2007. Petrology, geochemistry and tectonic significance of Paleoproterozoic alkaline lamprophyres from the Jungel valley, Mahakoshal supracrustal belt, central India. Mineralogy and Petrology, 89: 189-215.

Stöcklin, J., 1968. Structural history and tectonics of Iran; a review. AAPG Bulletin, 52: 1229-1258.

Stöcklin, J., 1977. Structural correlation of the Alpine ranges between Iran and Central Asia. Mémoire Hors-Serie, Société géologique de France, 8: 333-353.

Stoneley, R., 1981. The geology of the Kuh-e Dalneshin area of southern Iran, and its bearing on the evolution of southern Tethys. Journal of the Geological Society, 138: 509-526.

Sun, S.S., McDonough, W.F., 1989. Chemical and isotopic systematic of oceanic basalts: implications for mantle composition and processes. Geological Society Special Publications, 42: 313-345.

Thorpe, R.S., 1982. Andesites, Orogenic Andesites and Related Rocks. John Wiley \& Sons.

Van Hunen, J., Allen, M.B., 2011. Continental collision and slab break-off: a comparison of 3-D numerical models with observations. Earth and Planetary Science Letters, 302: 27-37.

Velikoslavinsky, S.D., Krylov, D.P., 2014. Geochemical discrimination of basalts formed in major geodynamic settings. Geotectonics, 48: 427-439.

Wedepohl, K.H., 1995. The composition of the continental crust. Geochimica et Cosmochimica Acta, 59: 1217-1232.

Wilson, M, 2007. Igneous Petrogenesis: A Global Tectonic Approach. Springer.

Winter, J.D., 2014. Principles of Igneous and Metamorphic Petrology. Pearson Education Limited.

Wood, D.A., 1980. The application of Th-Hf-Ta diagram to problems of tectonomagmatic classification and to establishing the nature of crustal contamination of basaltic lavas of the British Tertiary volcanic province. Earth and Planetary Science Letters, 50: 11-30.

Yousefi, S.J., Moradian, A., Ahmadipour, H., 2017. Petrogenesis of Plio-Quaternary basanites in the Gandom Beryan area, Kerman, Iran: geochemical evidence for the low-degree partial melting of enriched mantle. Turkish Journal of Earth Sciences, 26: 284-301.

Zor, E., 2008. Tomographic evidence of slab detachment beneath eastern Turkey and the Caucasus. Geophysical Journal International, 175: 1273-1282. 